\title{
Latent Infection of Austrian and Scots Pine Tissues by Sphaeropsis sapinea
}

\author{
J. Flowers, E. Nuckles, J. Hartman, and L. Vaillancourt, Department of Plant Pathology, University of Kentucky, \\ Lexington 40546-0091
}

\begin{abstract}
Flowers, J., Nuckles, E., Hartman, J., and Vaillancourt, L. 2001. Latent infection of Austrian and Scots pine tissues by Sphaeropsis sapinea. Plant Dis. 85:1107-1112.

This study documents latent infection of Austrian and Scots pine tissues by Sphaeropsis sapinea, the causal agent of Sphaeropsis tip blight disease. Symptomless shoots from diseased or apparently healthy Austrian and Scots pine trees were cultured and analyzed for the presence of S. sapinea. Nearly half of the sampled Austrian and Scots pine trees that appeared to be completely healthy had detectable latent $S$. sapinea infections. More than half of the symptomless shoots on visibly diseased Austrian and Scots pine trees were also latently infected with $S$. sapinea. S. sapinea was isolated from symptomless shoot stems, needles, buds, immature cones, and male flowers. In symptomless infected shoots, the fungus was primarily associated with the bark and phloem tissues. Six isolates of $S$. sapinea from symptomless Austrian and Scots pine shoot tissues were pathogenic on Austrian pine seedlings in the greenhouse. The presence of $S$. sapinea in symptomless tissues of tip blight-diseased trees has important implications for disease management.
\end{abstract}

Additional keywords: Diplodia pinea, Diplodia tip blight

Sphaeropsis sapinea (Fr.:Fr) Dyko \& Sutton in Sutton (syn. Diplodia pinea (Desmaz.) J. Kickx fil.) causes Sphaeropsis tip or shoot blight (previously known as Diplodia tip blight) on more than 30 species of pines, as well as on some other conifers. Tip blight is common worldwide and can result in serious economic losses, especially on exotic or native trees growing in managed plantations $(20,23,25)$. Severe damage most frequently has been associated with drought and other environmental stresses on the host trees (1$3,10,12,16)$. In addition to blighted shoot tips, S. sapinea can also cause seedling damping-off and collar rot, root disease, stem cankers, top dieback, and blue stain of cut timber, $(11,12,14,16,20,22,24)$.

$S$. sapinea has no known sexual stage in its life cycle. Conidiospores are released in the northern hemisphere during wet periods between March and October from pycnidia that are produced on mature cones and on killed shoots and needles (13). Infection studies have established that conidial germ tubes enter stomata of needles on young shoots before the shoots elongate in early spring (16). Infected shoots stop

Corresponding author: L. Vaillancourt

E-mail: vaillan@pop.uky.edu

This is paper number 01-12-81 from the Kentucky Agricultural Experiment Station, published with the permission of the director.

Accepted for publication 25 June 2001.

Publication no. D-2001-0820-02R

(C) 2001 The American Phytopathological Society growing and quickly die, resulting in the typical tip blight syndrome (16). The fungus may also infect elongating shoots later in the season, and it readily invades wounds caused by insects, pruning, or other factors $(7,22,25)$.

During the past 10 years, Sphaeropsis tip blight has emerged as a serious problem in Kentucky and Ohio on Austrian (Pinus nigra Arnold) and Scots pines (P. sylvestris L.) in landscape settings, as well as in Scots pine Christmas tree plantations. In 1992, as part of an effort to understand why the severity of this disease appeared to be increasing, we began to monitor the progress of a Sphaeropsis tip blight epidemic among 563 landscape Austrian pine trees on and around the University of Kentucky campus. The trees ranged in age from 7 to 30 years old, and were planted singly, or in groups of up to 72 trees. The tip blight disease was nearly absent in pines that were less than 13 years old, but it became progressively worse as the trees aged (8). This was true regardless of the proximity of diseased trees in the same or nearby landscape groups. Onset of disease symptoms was most closely associated with the production of cones. Since 1992, more than half of this original population of Austrian pine trees has been removed due to severe tip blight disease. As an example of the impact of this disease, one landscape group of 19 Austrian pine trees was planted in 1977, and all of the trees remained healthy and became well established during the 1980s. However, by 1992 all of the trees had developed tip blight symptoms, which continued to worsen over the next several years. The last of these trees was finally removed due to severe tip blight in 1999. During 1999 alone, more than 50 Austrian pine trees on the University of Kentucky campus were removed because of tip blight. Tip blight disease continued to kill these Austrian pines throughout the 1990s, even though they were regularly and aggressively treated by the university groundskeepers following control protocols recommended by the University of Kentucky cooperative extension service (9). The treatment consists of protectant fungicide sprays beginning at budbreak and repeated at 2-week intervals until needles are fully elongated, as well as pruning of dead and dying shoots and branches, and removal of heavily diseased trees from the landscape to reduce inoculum levels.

It has been reported that $S$. sapinea can persist in shoots of apparently healthy jack pine ( $P$. banksiana Lamb.) and red pine $(P$. resinosa Ait.) seedlings and saplings in Wisconsin (21), as well as in needles and cones from apparently healthy trees of other pine species in South Africa $(5,19)$. We considered the possibility that control failures on the University of Kentucky campus and elsewhere in our region might be related to latent infections of healthyappearing tissues on diseased trees. Latent infection of symptomless tissues on diseased trees had not been reported previously. The recommended controls, particularly pruning and spraying of diseased trees, might be less effective if the fungus is already present in tissues that appear healthy, and if the fungus in these latently infected tissues has the potential to cause disease. Our first objective in this study, therefore, was to determine the extent of infection by $S$. sapinea of symptomless tissues from diseased and apparently healthy Austrian and Scots pines. Our second objective was to determine if $S$. sapinea isolated from symptomless tissues was pathogenic in the greenhouse.

\section{MATERIALS AND METHODS}

Field survey. To describe the extent of latent Sphaeropsis infection among local Austrian and Scots pines, we conducted a random survey in which we sampled more than 800 symptomless shoots collected from 120 tip blight-diseased or apparently healthy trees. A smaller number of blighted shoots were also collected from the diseased trees as controls. Samples were collected between December 1998 and February 2001. A majority of the samples were collected between the months of July and 
March, and consisted of the youngest lignified shoot and its associated terminal bud, cones (Fig. 1), or male flowers. A smaller number of samples were collected between April and June, and these consisted of the
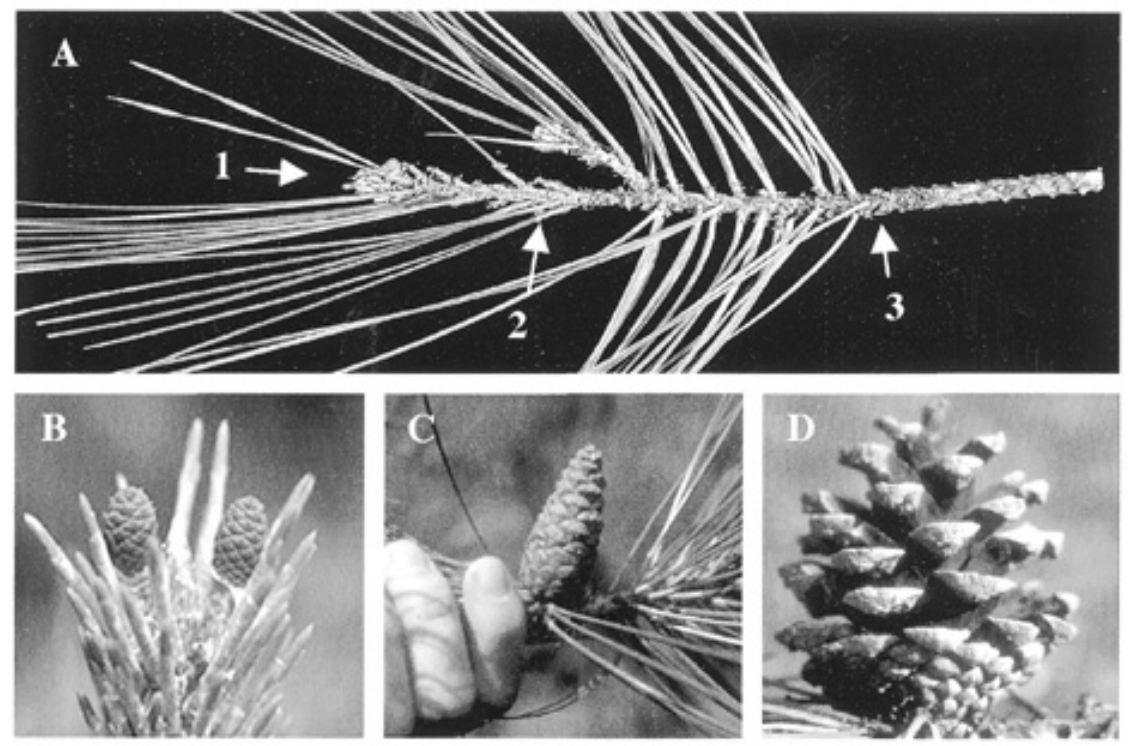

Fig. 1. Examples of the Austrian pine tissues that were sampled for this study. A, Terminal shoot. 1, terminal bud; 2, most recent year's lignified shoot; 3, previous year's growth. Most of the needles were removed from this healthy shoot for the photograph in order to reveal the underlying structure. B, First-year cones (purple cones); C, second-year cones (green cones); D, third-year (opened) cones.
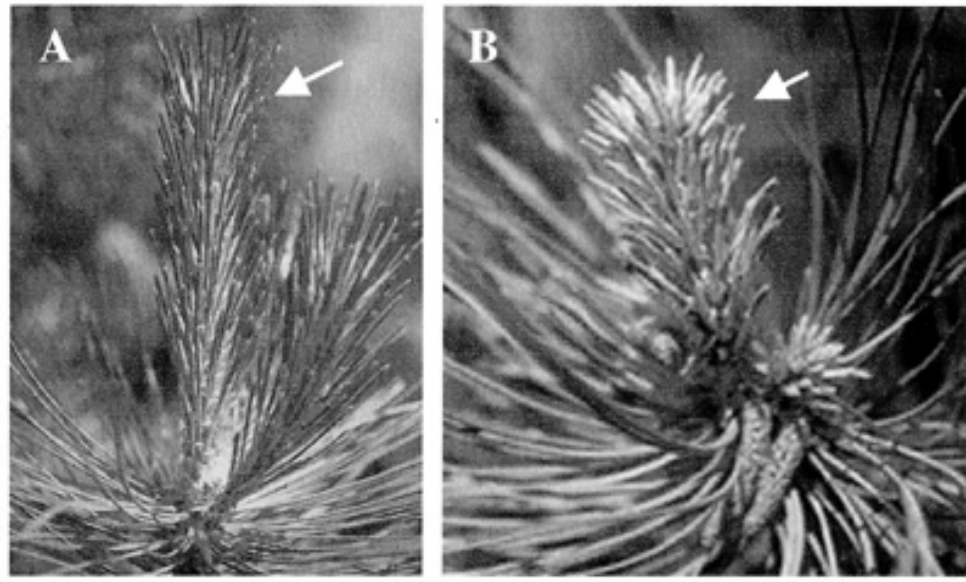

Fig. 2. Austrian pine shoots photographed in early May. A, Healthy shoot tip with an elongating candle (arrow). B, Blighted shoot tip (arrow) that has been killed by Sphaeropsis sapinea. that were sampled are summarized in Table 1. Disease severity was determined by estimating the number of blighted shoots as a percentage of the total number of shoots on the tree. Trees rated as apparently healthy, or symptomless, had no visible signs or symptoms of Sphaeropsis tip blight.

Shoots were cut from the trees and placed separately into polythene storage bags, then kept up to 2 weeks at $4^{\circ} \mathrm{C}$ until they were processed for culturing. Entire shoots, with needles attached, were surface disinfested by submerging them for $10 \mathrm{~min}$ in a solution of $10 \%$ bleach containing a few drops of Tween 20, followed by two rinses in sterile deionized water for $5 \mathrm{~min}$ each. The efficacy of this method was tested by pressing the surfaces of selected uncut control or uncut disinfested shoots (with needles present or removed) as well as isolated needles onto nutrient media (Difco Luria-Bertani and potato dextrose agar [PDA]). Few saprophytic fungi or bacteria, and no $S$. sapinea, were recovered from the surfaces of disinfested symptomless tissues.

Surface-disinfested shoots were dried between layers of sterile paper towels, then separated into stems, needles, buds, cones, and male flowers (if any; Fig. 1A-D). Subsamples of these tissues were cultured on PDA (Difco) acidified with $85 \%$ lactic acid at $1 \mathrm{ml} /$ liter (APDA). Subsamples consisted of the following: $1-\mathrm{cm}$ crosssections of stem tissue taken from near the top and the bottom of lignified shoots and elongated candles; entire buds, male flowers, small candles (less than $3 \mathrm{~cm}$ long), or first and second year cones (Fig. 1B and C), split longitudinally; individual whole needles with fascicle sheaths removed; and individual scales from opened cones (Fig. 1D). Inoculated culture plates were incubated under ambient laboratory temperature and light conditions for 4 to 7 days. Colonies with fluffy, fast-growing aerial mycelium typical of $S$. sapinea were subcultured onto $2 \%$ water agar plates containing autoclaved Austrian pine needles. Production of pycnidia containing conidiospores of $S$. sapinea confirmed the identity of the colonies.

Localization of $S$. sapinea in infected pine tissues. In all, 19 blighted and 37

Table 1. Characteristics of trees and shoots sampled to determine the extent of latent infection of Austrian and Scots pines by Sphaeropsis sapinea

\begin{tabular}{|c|c|c|c|c|}
\hline \multirow[b]{2}{*}{ Characteristic } & \multicolumn{2}{|c|}{ Austrian pines } & \multicolumn{2}{|c|}{ Scots pines } \\
\hline & Symptomless $^{\mathrm{a}}$ & Tip blight diseased ${ }^{\mathbf{b}}$ & Symptomless & Tip blight diseased \\
\hline Number of trees sampled & 31 & 65 & 10 & 14 \\
\hline Number of symptomless shoots sampled & 211 & 554 & 17 & 32 \\
\hline Number of symptomatic shoots sampled ${ }^{c}$ & & 29 & $\ldots$ & 23 \\
\hline Average age of sampled trees (years) & 10.7 & 17.8 & 8.5 & 11.3 \\
\hline Age range (years) & $6-17$ & $10-25$ & $3-12$ & $7-20$ \\
\hline Average disease rating of sampled trees ${ }^{\mathrm{d}}$ & $\ldots$ & $42 \%$ & $\ldots$ & $25 \%$ \\
\hline Disease range & $\ldots$ & $1-90 \%$ & $\ldots$ & $5-65 \%$ \\
\hline
\end{tabular}

a Symptomless: apparently healthy, with no symptoms of tip blight disease.

${ }^{\mathrm{b}}$ Tip blight diseased: obvious symptoms of Sphaeropsis tip blight were present.

c Symptomatic: shoots displaying obvious tip blight symptoms.

${ }^{\mathrm{d}}$ Disease rating: tip blight disease rating determined by estimating the number of blighted shoots as a percentage of all the shoots on the tree. 
symptomless, latently infected shoots were collected from 33 tip blight-diseased Austrian pine trees in the Lexington area during the fall of 1999 and during the winter of 2001. The shoots were surface disinfested as described above, and 1-cm crosssections were removed from the top and from the base of the stem and dissected into bark (consisting of the epidermis, the periderm, and a portion of the cortex), phloem (consisting of the remainder of the cortex and the phloem), xylem, and pith tissues. The dissected tissues were surface disinfested a second time in a $10 \%$ bleach solution, followed by two rinses in sterile deionized water, and S. sapinea was cultured and identified from the tissue pieces as described. ternal to the cambium) from branches bearing blighted shoots, or from branches bearing only healthy shoots, were collected from several tip blight-diseased trees on the University of Kentucky campus in the fall of 1999. Four Austrian pines and one Scots pine were sampled. A \#2 cork borer was used to recover bark from branches that were formed in 1998 and 1996, and a \#4 cork borer was used to obtain samples originating in 1994 and also to sample the main trunks of the trees. Each sample was dissected into three portions: the first and outermost (referred to as "bark") consisted of most of the periderm; the second (re-
Samples of bark tissues (all tissues ex-

ferred to as "cortex") consisted of a portion of the periderm, the cortex, and part of the primary phloem; and the third and innermost (referred to as "phloem") consisted of the remainder of the primary phloem and the secondary phloem. All dissected subsamples were surface disinfested in $10 \%$ bleach followed by two rinses in sterile deionized water, and plated on APDA. $S$. sapinea was cultured and identified as described.

The relationship between tip blight disease severity and the degree of latent infection. Sixty-four Austrian pine trees planted in landscapes throughout the city of Lexington, KY, were randomly chosen for this experiment. These included 15 apparently healthy trees; 11 trees with 1 to $20 \%, 10$ trees each with 25 to $40 \%$, or 45 to $60 \%$ blighted shoots; and 9 trees each with 65 to $80 \%$ or $>80 \%$ of the shoots blighted by $S$. sapinea. Ten symptomless shoots were collected at random from each tree between December 2000 and February 2001, and each shoot was dissected and cultured to detect the presence of $S$. sapinea using the same procedure that was used for the random survey.

Greenhouse inoculations. Ninety apparently healthy 3-year-old Austrian pine seedlings used for greenhouse inoculations were received from Musser Forests, Inc. (Indiana, PA) in fall 1999. It has been reported that nursery seedlings of red pine

Table 2. Results of inoculation of Austrian pine seedlings in the greenhouse with Sphaeropsis sapinea isolates obtained from diseased or asymptomatic Austrian and Scots pine shoots

\begin{tabular}{llc}
\hline Isolate & \multicolumn{1}{c}{ Source $^{\mathbf{a}}$} & Diseased/symptomless $^{\mathbf{b}}$ \\
\hline $125-1$ & Symptomless Austrian pine shoot & $2 / 4$ \\
$103-1$ & Symptomless Austrian pine shoot & $6 / 0$ \\
$15-$ SB & Symptomless Austrian pine shoot & $3 / 3$ \\
$61-$ SB & Symptomless Austrian pine shoot & $5 / 1$ \\
$12-\mathrm{S}$ & Diseased Austrian pine shoot & $5 / 1$ \\
$70-\mathrm{D}$ & Diseased Austrian pine shoot & $4 / 2$ \\
$21-\mathrm{S}$ & Diseased Austrian pine shoot & $4 / 2$ \\
$28-\mathrm{A}$ & Symptomless Scots pine shoot & $5 / 1$ \\
$113-1$ & Symptomless Scots pine shoot & $5 / 1$ \\
$144-3$ & Diseased Scots pine shoot & $6 / 0$ \\
$150-2$ & Diseased Scots pine shoot & $4 / 2$ \\
Control & $\ldots$ & $0 / 9$ \\
\hline
\end{tabular}

${ }^{a}$ Symptomless: apparently healthy, with no symptoms of tip blight disease. Diseased: symptoms of tip blight disease were present.

${ }^{b}$ Number of diseased plants/number of symptomless plants at 11 weeks after inoculation. can be symptomless carriers of $S$. sapinea (21), so 15 of these Austrian pines were randomly selected and stems, needles, and buds were cultured as described for the random survey. $S$. sapinea was not isolated from any of these seedlings. Eleven isolates of $S$. sapinea were selected for greenhouse inoculations: four from latently infected shoots of Austrian pine; three from diseased shoots of Austrian pine; two from latently infected shoots of Scots pine; and two from diseased shoots of Scots pine (Table 2). Each isolate was used to inoculate six Austrian pine seedlings in the greenhouse. The remaining nine seedlings were used as controls. Inoculations were made by using a sterile scalpel to make a shallow wound on the terminal shoot, approximately $5 \mathrm{~cm}$ below the apex, and placing a small plug of inoculum cut from an actively growing culture of $S$. sapinea on PDA under the resulting wounded tissue. Noncolonized PDA plugs were placed on the similarly wounded control seedlings. All wound sites were wrapped in parafilm, which was removed after incubation for $24 \mathrm{~h}$. The treated seedlings were placed in a completely randomized arrangement on the greenhouse bench. Seedlings were spaced far enough apart to prevent contact between them. Trees were rated for symptoms at 11 weeks after inoculation. Needle and stem samples were removed from diseased or symptomless shoot tips and were cultured on APDA for $S$. sapinea. The identity of the fungus was confirmed by culturing on water agar containing pine needles as described above.

\section{RESULTS}

Field survey. S. sapinea was recovered from all of the symptomatic shoot samples, as expected (Table 3). S. sapinea also was frequently isolated from symptomless shoots of both apparently healthy and obviously diseased Austrian and Scots pines. The fungus was recovered from $49 \%$ percent of the symptomless Austrian and Scots pine trees. S. sapinea also was isolated from more than half of the symptomless shoots sampled from trees that had obvious symptoms of tip blight disease on other shoots. There was a higher degree of latent infection noted among apparently

Table 3. Extent of latent infection of Austrian and Scots pines by Sphaeropsis sapinea ${ }^{\mathrm{a}}$

\begin{tabular}{lccccc}
\hline & \multicolumn{2}{c}{ Austrian pines } & & \multicolumn{2}{c}{ Scots pines } \\
\cline { 2 - 3 } \cline { 5 - 6 } Infected $^{\mathbf{b}}$ & Symptomless $^{\mathbf{c}}$ & Tip blight diseased $^{\mathbf{d}}$ & & Symptomless $^{\mathbf{e}}$ & Tip blight diseased $^{\mathbf{f}}$ \\
\hline Percent infected trees & 39 & 100 & 70 & 100 \\
Percent infected symptomatic shoots & $\ldots$ & 100 & $\ldots$ & 100 \\
Percent infected symptomless shoots & 8 & 55 & 59 & 66 \\
\hline
\end{tabular}

a Symptomless: apparently healthy, with no symptoms of tip blight disease. Tip blight diseased: obvious symptoms of Sphaeropsis tip blight disease were present.

b Infected: S. sapinea was recovered from at least one cultured tissue subsample. Symptomatic: shoots displaying tip blight symptoms.

c Total of 31 trees: 29 from Lexington, KY and 2 from Bloomington, IN.

${ }^{\mathrm{d}}$ Total of 65 trees: 60 from Lexington, KY; 3 from Bloomington, IN; 1 from Dublin, OH; and 1 from Urbana, IL.

${ }^{\mathrm{e}}$ Total of 10 trees: 5 from Lexington, KY; 3 from Lancaster, OH (Christmas tree farm); and 2 from Spring Valley, OH (Christmas tree farm).

${ }^{f}$ Total of 14 trees: 5 from Lexington, KY; 1 from Dublin, OH; 1 from Plano, IL; 4 from Lancaster, OH (Christmas tree farm); and 3 from Spring Valley, $\mathrm{OH}$ (Christmas tree farm). 
healthy Scots pine trees (70\%) than among apparently healthy Austrian pine trees (39\%); this was true for Scots pines sampled from landscapes as well as for those sampled from Christmas tree farms. Although there was considerable variability in the rate of recovery of $S$. sapinea from symptomless shoots on individual Austrian pine trees, this variation could not be related to the location of the trees, proximity of other diseased or healthy trees, or the time of year that the collection was made.

$S$. sapinea isolates that we recovered from symptomless and diseased tissues of Scots and Austrian pines had the typical "type A" morphology. We did not recover any colonies with the "type B" morphology. Type B is a less common morphotype that was originally described in the northcentral United States $(4,12,15,18,22)$. Our failure to recover a type B isolate may have been related to our isolation protocol, because we only picked colonies that had the typical fluffy, fast-growing phenotype of the type A S. sapinea for further analysis. All of our isolates were similar in growth rate and colony appearance on PDA, and all produced pycnidia and conidia typical of $S$. sapinea on autoclaved Austrian pine needles on water agar.

$S$. sapinea was recovered from all parts of the symptomless shoots, including needles, stems, buds, immature cones, and male flowers. It has been reported that immature cones are not infected by $S$. sapinea (16), but we were able to isolate the fungus from these tissues, although we observed pycnidia only on the opened cones.

Localization of $S$. sapinea in infected pine tissues. $S$. sapinea was confined pri- marily to stem tissues in symptomless, latently infected Austrian pine shoots; whereas, in shoots displaying symptoms of tip blight disease, the fungus was found in the needles and the bud as well as the stem (Fig. 3). Of the 53 symptomless Austrian pine shoots with elongating candles that were sampled during the months of April through June, 21 were latently infected with $S$. sapinea. In 5 of these latently infected shoots, the fungus was recovered only from the stem of the previous year's fully lignified shoot and not from the candle; in 1 it was recovered only from the stem of the elongating candle and not from the lignified shoot; and in 15 of the shoots, $S$. sapinea was recovered from the stems of both the previous year's lignified shoot and the elongating candle.

We isolated $S$. sapinea primarily from the bark and phloem tissues of symptomless Austrian pine shoots, and only rarely found it in the xylem and pith. In contrast, it was commonly isolated from all four tissue types in tip blight-diseased shoots (Fig. 4).

S. sapinea was recovered from the main trunks of two of five diseased Austrian and Scots pine trees sampled. It was found in the bark, and less frequently in the cortex, of the healthy branches, and could be easily recovered from the bark, cortex, and phloem of branches bearing diseased shoots (data not shown).

The relationship between tip blight disease severity, tree age, and the degree of latent infection. The only factors that were related to the degree of latent infection were the severity of tip blight disease on the tree and the age of the tree (Fig. 5).

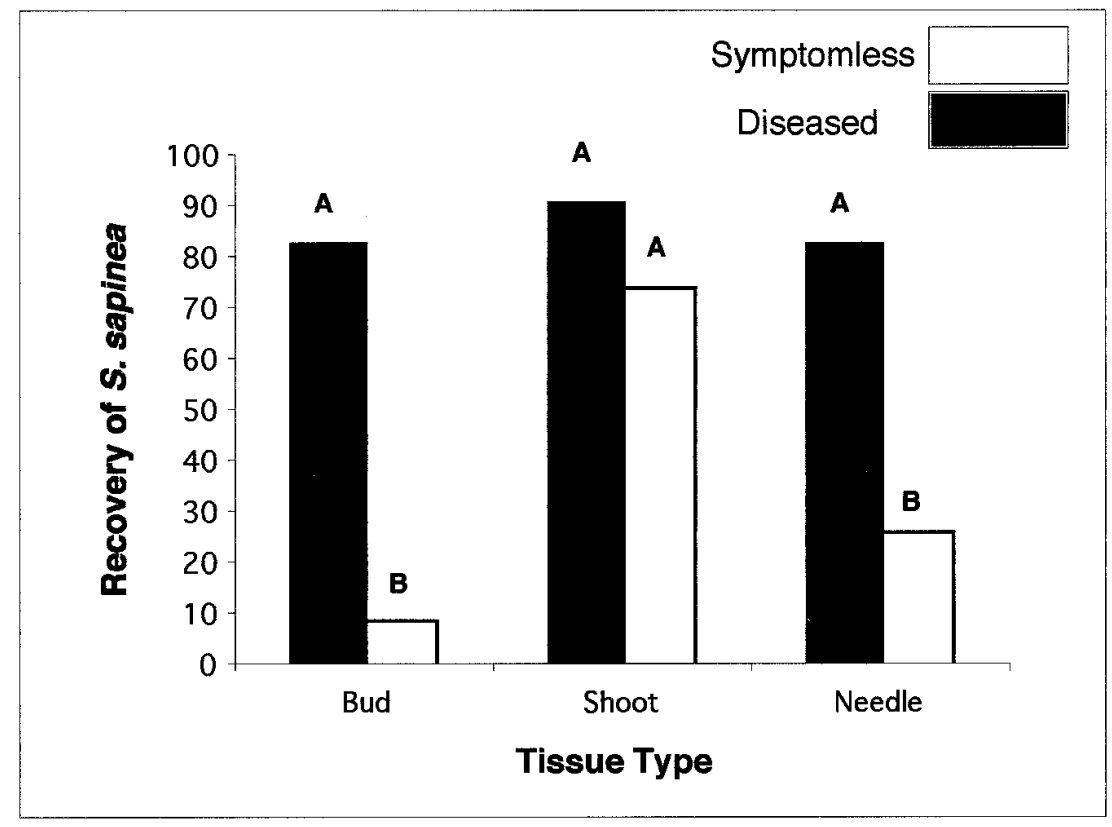

Fig. 3. Recovery of Sphaeropsis sapinea within diseased or symptomless, latently infected shoots of Austrian pine. Cultured tissues included the terminal buds, stems, and needles from the most recent year's lignified shoot. In all, 23 diseased and 23 symptomless shoots were included in the analysis. Bars within the same series that have the same letter were not significantly different according to a Waller-Duncan test at a significance level of $\alpha=0.5$.
There was a significantly higher degree of latent infection of symptomless shoots in trees where more than $20 \%$ of the shoots on the tree had tip blight symptoms than in trees with fewer diseased shoots (Fig. 5A). Both latent infection rate and tip blight disease severity were related to tree age (Fig. 5B and C).

Greenhouse inoculations. All the $S$. sapinea isolates, including those from latent infections, were pathogenic and caused symptoms typical of tip blight within 2 weeks of inoculation (Table 2). All controls remained healthy and symptomless. Subsamples of diseased tissues from the seedlings were cultured, and $S$. sapinea was recovered from all of these. $S$. sapinea was not recovered from any of the control trees.

Of the 66 inoculated trees in the greenhouse, 17 (26\%) had not developed tip blight symptoms 11 weeks after inoculation, when the experiment was stopped (Table 3). Of these, 10 trees had been inoculated with fungal isolates recovered from latent infections, and the other 7 had been inoculated with fungal isolates from diseased tissues. Terminal shoot tips down to approximately $20 \mathrm{~cm}$ below the inoculation wounds were removed from 10 of the symptomless trees after 11 weeks, surface sterilized, dissected, and cultured as described for the random survey. Nine of the trees contained $S$. sapinea within stem

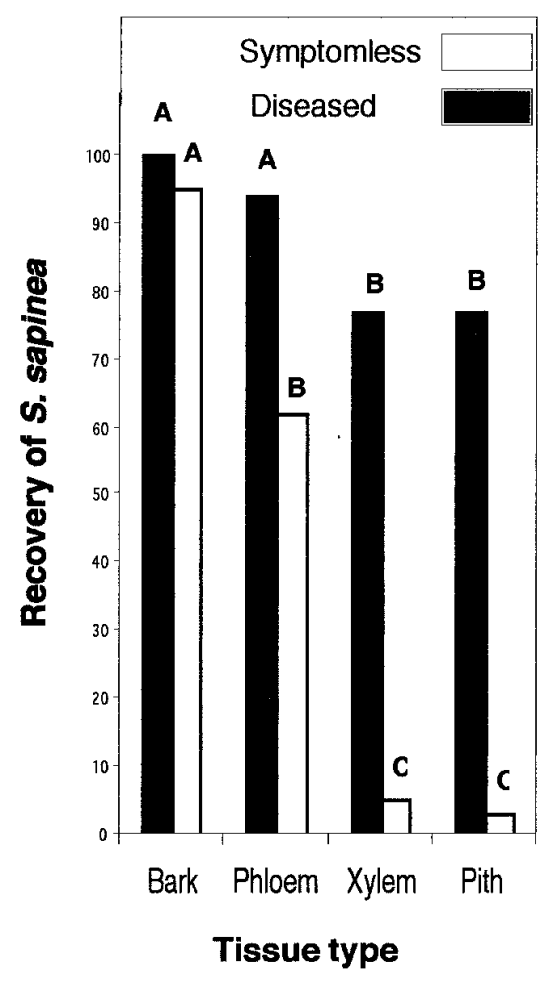

Fig. 4. Recovery of Sphaeropsis sapinea within stems of diseased or symptomless, latently infected Austrian pine shoots. Bars within the same series that have the same letter were not significantly different according to a WallerDuncan test at a significance level of $\alpha=0.5$. 
tissues and needles at least $5 \mathrm{~cm}$ beyond the original inoculation site. Six of these nine trees had been inoculated with strains recovered from diseased tissues, and the other three were inoculated with isolates from latent infections.

\section{DISCUSSION}

Reports that $S$. sapinea could be isolated from symptomless tissues of healthy pine trees became particularly relevant to us when we began to see an increase in the severity of Sphaeropsis tip blight on Austrian and Scots pines in our region about 10 years ago. We were particularly disturbed by the apparent ineffectiveness of our recommended management protocols in slowing the progress of the tip blight disease. We wanted to discover whether latent infections might be a factor in these

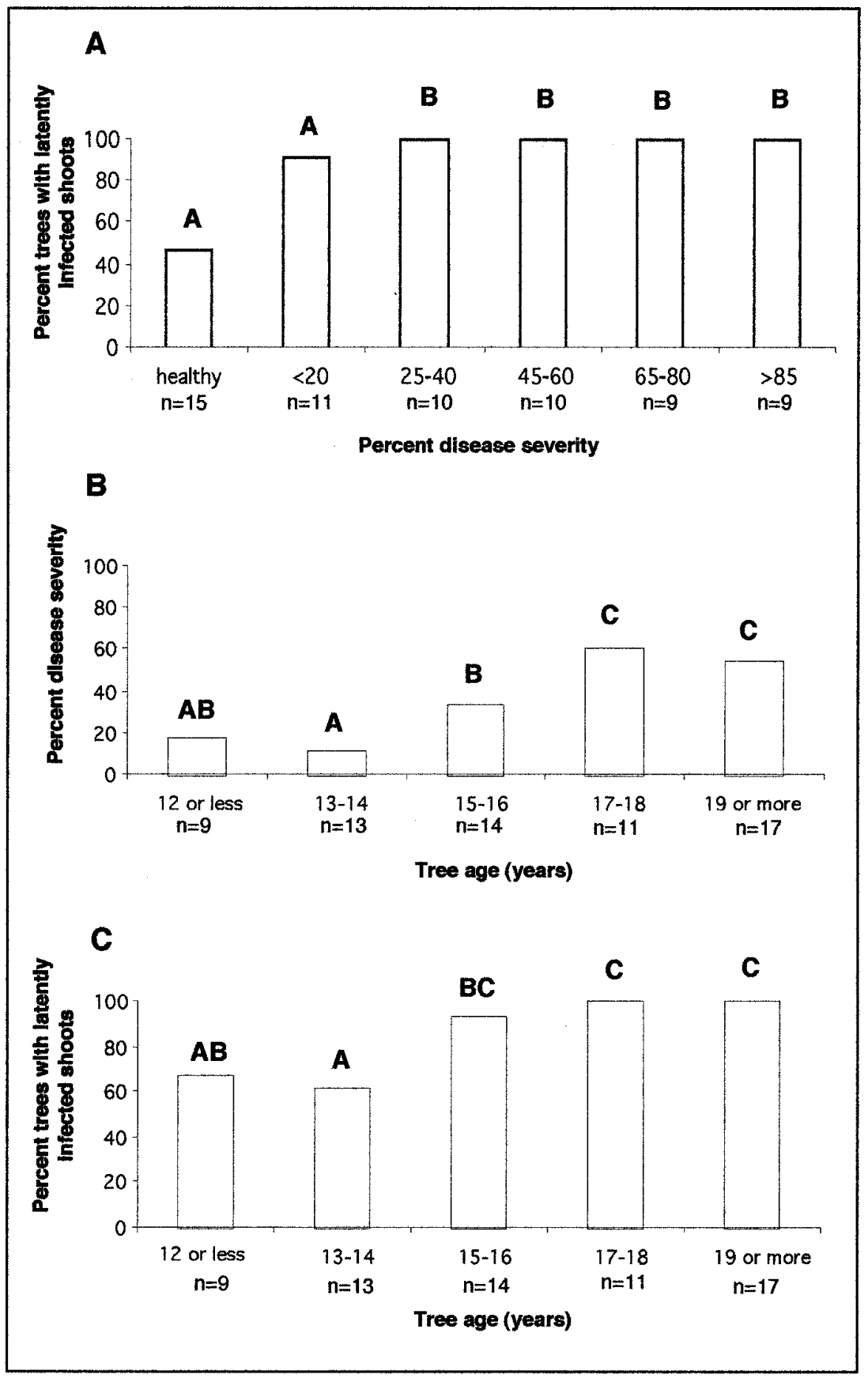

Fig. 5. Relationships among tree age, disease severity, and degree of latent infection of symptomless shoots within a population of 63 tip blight-diseased or symptomless Austrian pine trees. A, Relationship between the degree of latent infection and tip blight disease severity; $\mathbf{B}$, relationship between tip blight disease severity and tree age; $\mathbf{C}$, relationship between the degree of latent infection and tree age. Bars within the same series with the same letters are not significantly different according to a Waller-Duncan multiple range comparison at a significance level of $\alpha=0.5$.

frequent failures of recommended control measures.

We found that latent infection with $S$. sapinea of healthy Austrian and Scots pines in our region is relatively common. In $49 \%$ of symptomless trees of both species, $S$. sapinea was recovered from at least one sampled shoot. This is comparable to the $33 \%$ of apparently healthy red pine saplings and the $57 \%$ of apparently healthy jack pine saplings in a Wisconsin forest that were latently infected with $S$. sapinea (21).

This is the first report of latent infection of symptomless shoots on diseased trees by S. sapinea. The few previous studies of latency have included only symptomless trees. Although it may not be surprising that the fungus is present in asymptomatic shoots of diseased trees as well as apparently healthy ones, it was important to test this assumption because the implications for disease management are significant. One generally recommended control measure is pruning of diseased shoots, but this would appear to have little more than cosmetic use if the fungus is already present in healthy-appearing tissues, and if it is capable of causing disease symptoms at a later date. Isolates from latent infections certainly have the potential to be pathogenic, as our greenhouse inoculation experiment and a previously published report (21) both demonstrate. However, we must emphasize that we have no direct evidence at this time that latent infections can eventually give rise to disease symptoms in the field.

The degree of latent infection was significantly higher in Austrian pine trees that had greater than $20 \%$ blighted shoot tips than it was in apparently healthy trees, or trees with fewer than $20 \%$ of their shoots blighted. The degree of latent infection and the severity of tip blight disease were both significantly higher on older trees. A similar relationship between disease severity and tree age has been reported previously (8).

Previous studies have found $S$. sapinea associated with the bark of healthy pine trees, but not with the wood $(10,17)$, and our dissection data agree with those reports. The latent fungus is associated with the bark and phloem, and is only rarely present in the xylem or pith tissues in symptomless shoots. Furthermore, the fungus is confined primarily to the stem of latently infected shoots, whereas it is found as frequently in peripheral tissues (buds, needles) as in the stem of diseased shoots. It has been reported that the pathogen frequently produces aggregated hyphal masses within substomatal cavities on infected needles (6) or on the surfaces of young stems (7). It has been suggested that $S$. sapinea persists in this form in latently infected tissues (21).

Our observation that many of the apparently healthy shoots on diseased pine trees 
are already infected with $S$. sapinea has caused us to modify our recommendations for control of the Sphaeropsis tip blight disease. We now advise homeowners, landscapers, and Christmas tree growers to avoid planting Austrian pines or Scots pines in our region, because of the difficulty of controlling this disease, and we suggest the latency phenomenon as a likely explanation for the general ineffectiveness of pruning or spraying regimes. Because the connection between stress and tip blight disease severity is well established in the literature $(1-3,10,12,16)$, we are now emphasizing the maintenance of a stressfree environment as the primary mechanism for prevention and management of this disease, both in the landscape and in Christmas tree plantations. At this time we don't know if there is a connection between stress and latency, but this will be an interesting question to address in the future.

\section{ACKNOWLEDGMENTS}

We thank the Kentucky Nursery/Landscape Fund for financial support; B. Poupard and S. Kihl, undergraduate students at ENESAD de Dijon in France, who contributed greatly to this work during summer exchange visits to Lexington in 1998 and 1999; and D. Brown for excellent technical support.

\section{LITERATURE CITED}

1. Bachi, P. R., and Peterson, J. L. 1985. Enhancement of Sphaeropsis sapinea stem invasion of pines by water deficits. Plant Dis. 69:798-799.

2. Blodgett, J. T., Kruger, E. L., and Stanosz, G. R.. 1997. Effects of moderate water stress on disease development by Sphaeropsis sapinea on red pine. Phytopathology 87:422-428.

3. Blodgett, J. T., Kruger, E. L., and Stanosz, G. R. 1997. Sphaeropsis sapinea and water stress in a red pine plantation in central Wisconsin. Phytopathology 87:429-434.

4. Blodgett, J. T., and Stanosz, G. R. 1997. Sphaeropsis sapinea morphotypes differ in aggressiveness, but both infect nonwounded red or jack pines. Plant Dis. 81:143-147.

5. Botes, W. M., Swart, W. J., and Crous, P. W. 1996. Frequencies of fungal endophytes isolated from pine needles in South Africa. (Abstr.) Phytopathology 86:S66.

6. Brookhouser, L. W., and Peterson, G. W. 1971. Infection of Austrian, Scots and ponderosa pines by Diplodia pinea. Phytopathology 61:409-414.

7. Chou, C. K. S. 1978. Penetration of young stems of Pinus radiata by Diplodia pinea. Physiol. Plant Pathol. 12:189-192.

8. Hartman, J., Mussey, G., and Fountain, W. 1994. Evaluation of landscape Austrian pines for tip blight disease. Univ. Ky. Nursery Landsc. Program Res. Rep. SR-94-1:31.

9. Hartman, J., Witt, M., Hershman, D., and McNeil, R. 1989. Woody Plant Disease Control Guide for Kentucky. Coop. Ext. Serv. Univ. Ky. Publ. ID-88.

10. Kowalski, T., and Kehr, R. D. 1992. Endophytic fungal colonization of branch bases in several forest tree species. Sydowia 44:137168.

11. Nicholls, T. H., and Ostry, M. E. 1990. Sphaeropsis sapinea cankers on stressed red and jack pines in Minnesota and Wisconsin. Plant Dis. 74:54-56.

12. Palmer, M. A. 1991. Isolate types of Sphaeropsis sapinea associated with main stem cankers and top-kill of Pinus resinosa in Minnesota and Wisconsin. Plant Dis. 75:507510.

13. Palmer, M. A., McRoberts, R. E., and Nicholls, T. H. 1988. Sources of inoculum of Sphaeropsis sapinea in forest tree nurseries. Phytopathology 78:831-835.

14. Palmer, M. A., and Nicholls, T. H. 1985. Shoot blight and collar rot of Pinus resinosa caused by Sphaeropsis sapinea in forest tree nurseries. Plant Dis. 69:739-740.

15. Palmer, M. A., Stewart, E. L., and Wingfield, M. J. 1987. Variation among isolates of
Sphaeropsis sapinea in the north centra United States. Phytopathology 77:944-948.

16. Peterson, G. W. 1977. Infection, epidemiology, and control of Diplodia blight of Austrian, ponderosa, and Scots pines. Phytopathology 67:511-514.

17. Petrini, O, and Fisher, P. J. 1988. A comparative study of fungal endophytes in xylem and whole stem of Pinus sylvestris and Fagus sylvatica. Trans. Br. Mycol. Soc. 91:233-238.

18. Smith, D. R., and Stanosz, G. R. 1995. Confirmation of two distinct populations of Sphaeropsis sapinea in the north central United States using RAPDs. Phytopathology 85:699-704.

19. Smith H., Wingfield, M. J., Crous, P. W., and Coutinho, T. A. 1996. Sphaeropsis sapinea and Botryosphaeria dothidia endophytic in Pinus spp. in South Africa. S. Afr. J. Bot 62:86-88

20. Stanosz, G. R., and Cummings Carlson, J. 1996. Association of mortality of recently planted seedlings and established saplings in red pine plantations with Sphaeropsis collar rot. Plant Dis. 80:750-753.

21. Stanosz, G. R., Smith, D. R., Guthmiller, M. A., and Stanosz, J. C. 1997. Persistence of Sphaeropsis sapinea on or in asymptomatic shoots of red and jack pines. Mycologia 89:525-530.

22. Stanosz, G. R., Swart, W. J., and Smith, D. R. 1999. RAPD marker and isozyme characterization of Sphaeropsis sapinea from diverse coniferous hosts and locations. Mycol. Res. 103:1193-1202.

23. Swart, W. J., and Wingfield, M. J. 1991. Biology and control of Sphaeropsis sapinea on Pinus species in South Africa. Plant Dis. 75:761-765.

24. Wingfield, M. J., and Knox-Davies, P. S 1980. Association of Diplodea pinea with a root disease of pines in South Africa. Plant Dis. 64:221-223.

25. Zwolinski, J. B., Swart, W. J., and Wingfield, M. J. 1995. Association of Sphaeropsis sapinea with insect infestation following hail damage of Pinus radiata. For. Ecol. Manag. 72:293-298. 